\title{
Proletarianisation
}

\section{John Hutnyk}

\begin{abstract}
This essay takes up the work of Bernard Stiegler to evaluate and critique his use of Marx and Engels' notion of proletarianization in the context of new media, television, education and activism. The impact of technology and the notion of the general intellect is measured against Stiegler's worry about a 'short circuit' that threatens humanity and requires a 'new critique'. Talk of an 'attention economy' might be better understood if we deploy a wider Marxist notion of proletarianization in relation to class consciousness and struggle. Rather than a forlorn complaint about the 'conspiracy of imbeciles' and the 'ruin' of public education, a more careful reading of Marx offers proletarianization as a resource in a struggle that is - also but not only - a 'battle for intelligence'.
\end{abstract}

Keywords proletarianization, cretinization, technology, education, general intellect, critique

\section{PROLETARIANISATION}

The future of Europe and the world must be thought from the question of the psycho-power characteristic of control societies, and whose effects have become massive and destructive. Psycho-power is the systematic organisation of the capture of attention made possible by the psychotechnologies that have developed with the radio (1920), with television (1950) and with digital technologies (1990), spreading all over the planet.

\section{Bernard Stiegler ${ }^{1}$}

There is a kind of unseemly scramble underway to cope with apparent changes in the technological and social composition of capital today. It is my argument that this scramble is symptomatic of a political failure and a danger that can be analysed with the help, albeit taken critically, of the work of Bernard Stiegler, and of course - as if it were necessary to even say this with Marx. Stiegler's is an unorthodox Marxism, which is not always a bad thing. He diagnoses an 'indeterminacy rising out of an always-accelerating future' and this opens the space for a 'battle for intelligence'. ${ }^{2}$ A key concept relevant to this battle is quite an old one - a somewhat expanded notion of proletarianisation, building upon Gilbert Simondon's notion of collective, technical and human 'individuation', ${ }^{3}$ but derived initially from comments by Marx and Engels in The Communist Manifesto. Stiegler calls 'proletarianisation' Marx's greatest contribution.

In the Manifesto, Marx and Engels refer to the way in which the capitalist
1. Bernard Stiegler, 'Within the limits of capitalism, economizing means taking care', Ars Industrialis, http:// arsindustrialis.org/ $\underline{\text { node/2922 - accessed }}$ 1 November 2010.

2. Bernard Stiegler, Taking Care of Youth and the Generations, Stanford, Stanford University Press, (2008) 2010, p68, henceforth $T C$ in the text.

3. Gilbert Simondon, Lindividuation psychique et collective, Paris, Aubier, 1989. 
4. Karl Marx and Friedrich Engels The Communist Manifesto, Harmondsworth, Penguin, (1848) 1967, p62.

5. Ibid., p70.

6. Bernard Stiegler, The Decadence of Industrial Democracies, Polity Press (2004) 2011, $\mathrm{p} 4,35$ and 60 , henceforth Decadence in the text. mode of production forces more and more people into dependency upon waged labour and they report how the lower strata of the middle class, 'the small tradespeople, shopkeepers, retired tradesmen generally, handicraftsmen and peasants' are sinking gradually into the proletariat. They explain that the 'diminutive capital' of these lower strata leaves them unable to compete with large scale Industry and this Industry also enforces the passing of specialised skills in the face of new methods of production. ${ }^{4}$ Finally, though the teleological trajectory here is not so simple, Marx and Engels stress that the rise of a proletarian consciousness and proletarian class interest, opposed to the bourgeois class and capital, signals the advent of a political struggle to overthrow the bourgeoisie so as to inaugurate a world in which 'the free development of each is the condition for the free development of all'. ${ }^{5}$

Stiegler has both a narrower and a more generalised sense of proletarianisation than Marx and Engels, and he wants to rethink the contemporary situation in which we find our lives saturated by what he calls 'psychotechnologies' - for which often the shorthand is television and Google. It is of course unclear what demarcation lines mark out proletarian status or not. For Stiegler, the entire middle class seems to have become proletarianised, subject to the power of retentional devices that manage the contradictions of capital with 'cultural control', 'consumption' and which produce 'impotence' and 'self destructive transgressions [passages à l'acte]'. ${ }^{6}$ No doubt most data input jobs qualify as impotence-making - inclusive of academics toiling away in the teaching factory - but this designation of everyone as proletarian differentiates neither regionally nor historically with regard to class composition or cultural character. Nevertheless, focussing upon technologies, work and skills, a schematic is given in the Manifesto of the Ars Industrialis group, co-founded by Stiegler:

We call proletarianization the process through which an individual or collective knowledge, being formalized through a technique, a machine, or an apparatus, can escape the individual - who thus loses this knowledge which was until then his knowledge. The first definitions of proletarianization, emerging from the analyses of Smith as well as Marx, made clear that pauperization results in the first place from the loss of savoir-faire of workers enslaved to machines, and no longer masters of their tools (craftsmen).

In the twentieth century, it was consumers who lost their savoir-vivre - replaced by apparatus, such as the television set, which kept children 'occupied,' and by services, such as the television network, which kept children 'occupied' through the apparatus for televisual reception, but in such a way as to create 'available brain time'. This loss led to a deprivation of recognition, sociability, and finally existence, generating the suffering of the consumer become miserable. 
But the intellectual workers of 'cognitive capitalism', the functions of which are increasingly confined within the parameters of information systems the principles of which they are unable to modify - frequently because they are unaware of them - are subjected as well to a proletarianization of higher cognitive functions where what is lost is that which constitutes the life of the spirit as a critical, that is, rational, authority, capable of theoretical selfformalizing and as such of being self-critical. ${ }^{7}$

In this updated notion of proletarianisation, the role of television, of children, of misery and the place of self-criticism are each foregrounded. Stiegler's contribution has implications that need to be considered in relation to the very idea of a global proletariat; it has consequences for evaluation of both constraints and openings in technical innovation; it demands attention in terms of shifting class relations and communications; and lastly, it requires a critical assessment and rethinking of the ways race, gender and concerns about resistance play out in different cultural and value formats. This is to evaluate the appropriation of Marx for new times, and this paper sets out to consider this use, the place of technology, the contexts - so as to prepare the ground for questioning of how the global might be taken into account, how events and values are marked and measured, just who are the contemporary proletariat and how is this expressed, presented, represented, or transmuted in reflexive theory-writing. The paper aims to re-examine television and education, to think again about youth, family and value, and to consider the general intellect over against (or as) that which makes us stupid or impotent and subject to a Capital that ruins lives.

\section{TELEVISION}

Television has been a long-term interest for Stiegler, and subject of an important book with Jacques Derrida, originally video-recorded conversations, called Echographies of Television. ${ }^{8}$ In the third volume of his projected five volume series Technics and Time, Stiegler returns to television, somewhat strangely critical of Pierre Bourdieu for doing a book of his televised discussions, ${ }^{9}$ but also interestingly offering a number of unfolding code-words for televisual forms, placing the 'industries of communication and information' at the 'very heart of technical systems for the production of material goods'. ${ }^{10}$ These code words appear as general terms for the convergence of 'audio-visual industries' or 'psychotechnologies' (Decadence, p8), while in Taking Care of Youth and the Generations, he worries that:

what parents and educators (when they are themselves mature) patiently, slowly, from infancy, year after year pass on as the most valuable things civilization has accumulated, the audiovisual industries systematically destroy, every day, with the most brutal and vulgar techniques, while
7. Ars Industrialis, Manifesto 2010 http://arsindustrialis. org/manifesto-2010, accessed 31 October 2010, my italics.

8. Jacques Derrida and Bernard Stiegler, Echographies of Television, Cambridge, Polity, (1996) 2002.

9. Pierre Bourdieu and $\mathrm{On}$ Television, New York, New Press, (1996) 1998.

10. Bernard Stiegler, Technics and Time, 3: Cinematic Time and the Question of Malaise, Stanford, Stanford University Press (2001) 2011, p133, henceforth TT3 in the text. 
accusing the family and the education system of disaster. This care-less-ness is the primary cause of the extreme attenuation of educational institutions as well as the family structure $(T C, \mathrm{p} 72)$.

Stiegler's wider concern with emergent technologies responds to this assault upon the values of civilisation. I will not yet contest his argument that civilisation is being destroyed by television, or that we should despair for a 'herdish nihilism' where a 'stupid passivity' means 'they [we?] no longer believe in anything, no longer want anything, no longer do anything' (Decadence, p60). At this level the hyperbole is clear - with oft-expressed alarm, Stiegler is concerned that when a baby sees the TV remote as its first preferred rattle this is a disaster inaugurating a battle of 'incomparable importance' (TC, p93). A battle for intelligence and for attention, this is at first a battle with television, where he 'does not want to say ... that you are to think the same as others ... [but] you necessarily watch [television] with others, at the same time as others ... [and so] ... television is a

11. Bernard Stiegler, Acting Out, Stanford, Stanford University Press, (2003) 2009, p70, henceforth $A O$ in the text. process that tends to make you conform to an average'. ${ }^{11}$

My first point is that this rendering of the problem is alarmist and patronising. Stiegler reports, from a quite small sample of relatively obscure sources, on the astonishing statistics for television consumption in the 'lower classes' in England. He marvels that nearly 75 per cent of children between 0 and 3 years have a television in their bedrooms (TC, p56). This is then linked to the likely development of attention deficit disorder and extrapolated globally into 'a global attention deficit disorder', which, in turn, is 'transferred to the professional adult world as the cognitive overflow syndrome' (TC, p57). There are at least two problems with this: first, even accepting the statistics suggests that it is not television that is the trouble here, but parenting and commodity abundance; secondly, the wild escalation to alleged cognitive overflow in adults is tenuous at best. The extensive television consumption of the class in question here - the 'lower classes' - is not significantly dissimilar to others, but the alleged overload of the professional adult is a questionable thesis in any case. Complaint about information gluttony is itself a kind of sales-hype or status claim: 'I'm so busy'. The diagnosis of 'a regression in intelligence' is not something we could adequately gauge from the admittedly often pseudo-intelligible activities of the professional class. The claims here are also undifferentially European, or EuroAmerican. This is not to say there are no problems with the technological and even televisual domination of large swathes of contemporary life worldwide, but ideological scaremongering might be tempered by a wider and more systematic evaluation and analysis of how television, or new modalities of capitalism, rewires both brain and work, globally.

There is of course too much of Stiegler's oeuvre to read if a comprehensive assessment is to be made, and among his most provocative arguments is that television is also potentially sometimes able, like art and the cinema, to solicit deep attention (TC, p85) - as detailed in the conversation with Derrida where Derrida says he could be 'tempted to utilize images in the presentation of 
knowledge' and to teach on television so long as he had a 20 hour programme and people would have to read in advance. ${ }^{12}$ Derrida sees this is dangerous otherwise, but there are greater dangers. When Stiegler follows Katherine Hayles in suggesting that today's youth are subject to brain modification via different media, he then writes as if he and his readers are the last literate generation, the last to read books like his book, and the last to care $(T C, \mathrm{p} 19)$. It may be churlish to react by noting that the same was said about comics in the 1930s, as well as, in their time, cinema, photography and film. Television too was welcomed in apocalyptic tones.

What is missing here so far is the question of why this was the case, as well as discussion of the stakes of the battle. We need an evaluation of the place of capital in this scenario. It is a capital that adapts, modifies its technical make-up accordingly, and yet does not, and cannot fully exhaust its workforce without anticipating extinction. This is an escalation which, irrationally, tends towards exhaustion even as the workforce is transformed and moulded in use, with psychotechnologies now refined into microtechnologies, which in turn 'have actually begun to modify the very structure of the body, including body shape ... reproductive - procreative - technologies, as well as the invention of new kinds of bodies ... genetic modifications, cloning and so on' ( $T C$, p34). Stiegler here refers again especially to 'cognitive overflow syndrome', which is a 'process of disaffection and disaffectation through cognitive as well as affective saturation' (TC, p212) - an overwhelming cascade of information that assaults and transforms the space of social, and economic, life. As if to prove the point, he offers a bewildering array of synonyms for this crisis: to take just a few pages from where he leaves us at the end of his book Taking Care, we read of 'disequilibrium', 'infantalizing hegemonies of various psychopowers', 'disindividuation ... deformation ... destruction', 'catastrophic effects on juvenile consciousness' and 'attentional deficits and intergenerational problems' (TC, pp180-191).

Proletarianisation is here a disaster which fosters mass distraction, or, in Marx's more precise word, a 'cretinisation'. This is the capture of attention in a grinning fascination with commodities that claim each to be different but are mass produced, congealed and alienated fetish objects. In Capital, Marx goes on to show how the tools, organisation, training methods and socio-economic forms of capital produce a mode of production rife with contradictions, that, in turn, the proletarians will fight:

the mass of misery, oppression, slavery and degradation grows; but with this there also grows the revolt of the working class, a class constantly increasing in numbers, and trained, united, and organised by the very mechanism of the capitalist process of production ... the centralization of the means of production and the socialization of labour reach a point where they become incompatible with their capitalist integument. The integument bursts asunder. ${ }^{13}$

13. Karl Marx, Capital Volume 1, Harmondsworth, Penguin, (1867) 1976, p929.

Integument is a translation of hülle, the outer husk or membrane of, for example, a seed, that must split apart for the plant to grow. Or perhaps not quite a seed's outer shell, but specifically the furry covered membrane which must part to let out none other than ... Marx himself, who makes so much of the labour that goes into a coat. 
Stiegler, however, accuses Marx of not understanding consumption (Decadence, p64). Yet Stiegler's own concern remains at the level of the family in Taking Care, when the destruction of long-circuits of being means sociality is destroyed by way of the loss of inter generational cooperation and through 'deterritorialized economic forces (and their programming industries)' (TC, p126).

Stiegler is arguing that what can be lost to television, audio-visual industries and psychotechnology-become-microtechnology, is the imaginative shared space of play within the family. This in turn is destroyed to the extent that the psychotechnologies of the culture industry take control of transitional objects and transitional spaces $(T C, \mathrm{p} 15)$. That baby rattle as remote carries a lot of weight in this argument, although some will say it is not clear that the mediated world of psychotechnologies does destroy such transitional spaces even if the objects are changed. Is it wise to dismiss the not unproblematic yet certainly significant impact of new technologies like Skype and videochat to connect absent parents and distant grandparents to internet-savvy kids? Even as these technologies are saturated commodities, might we recall the significance of mediated relationality in examples of, for instance, radio and television shared with mates at a distance, via mix tapes in the past, and via Spotify today? Or in the 'isolated' teenager finding ways to replicate pop, rock and hip-hop poses in the bedroom - a self-formation also 'at a distance' but not less mediated than face-to-face transindividuation unless one privileges the pastoral? Can we really say the contemporary post-Google situation is more commodified than the bourgeois family already always was - with all its psychotic investments and constraints? Care can also exist, and be lost, at a distance. There is both stupification and mechanisation, but it does not follow that televisual disconnect is inevitably an arrangement that only belongs to capitalism - which itself can be overthrown or sublated.

In the scramble to make sense of the changes that confront us, Stiegler is an interesting voice. I want to be careful not to present his comments about civilisation, genetics, body shape and other potentially normative formations as merely a defence of the bourgeois family, nor as an attack on the culture industry and television in the manner of a warmed-up caricatureAdorno. A more careful appreciation of what is at stake when accumulated civilisational merit is located in family relationships might consider new ways in which these values can be articulated without necessarily being coded and monetised in ways that Google can cash. The stake here is surely not that the traditional domestic and educational forms must be preserved, but that the appropriations of those with capital, the exploitation of relations of production and the consumptions that valorise those appropriations, might be sufficiently and fundamentally opposed. This means asking what it would mean to win against a capitalism that happily exploits television, nanotechnology and education as teaching factory. It also perhaps means winning against and by way of proletarianisation, and through stupidity and machines - stupification 
and mechanisation - as we shall see.

Stiegler's effort to address key problems of the contemporary social and political circumstance deserves a careful examination that perhaps looks more to continuities than to ruptures. The alleged 'upheaval' of communication systems and cybernetics might be taken in a less sensationalist mode, not to 'ignore or downplay' the developments entailed, since I agree that 'the very essence of cultures and societies is at stake' (TT3, p135) but to provoke a possibly different reading. A less techno-obsessive approach might claim both less and more of proletarianisation, as fear and love of technology equally fall under the spell of the ubiquitous commodity system. It may still be necessary to question Stiegler's somewhat circular view that 'enhancing the points of contact and communication devices between and among human groups means a tendency to reduce their ability to resist the concretizing process of technical tendencies' (TT3, p135).

What concerns Stiegler is that the 'interior milieux' of social groups are captured and dissolved by the 'exterior milieu' of the market in a synchronised 'radiophonic and televisual ... flux' (TT3, p136). The market, and the forces of capital signalled in that word, flux, are crucial contexts, but rather than the perpetuation of alarm over television, perhaps we might focus a more appropriate alarm upon capital in order to evaluate flux as an emergent and different density of the distribution of relationships of production. Like Marx thinking of co-operation in the factory, might we not imagine flux not only as algorithm for record sales and video hits on Youtube, but as a potential form of connectivity for those working collaboratively and politically to organise the atomised?

\section{ATTENTION AND EDUCATION}

international programming industries substitute for national institutions (national education systems) that no longer appear compatible with the new imperatives of transmission, as (now) defined by the global industrial mnemotechnical system. A true war of minds is at work in this evolution (TT3, p146)

Stiegler talks of evolution and a 'mutation' of the global capitalist system and calls for a 'new critique of political economy'. ${ }^{14}$ One, perhaps overly literary, way to renew Marx's critique is to consider narrative, which is of course also relevant to television, new media, and the transformations of family and education introduced by the cultural industries. Stiegler perhaps has this in mind when valorising the grandparent at play with the child, creating long-circuits of transmission that would include the favoured technology of the book, the storybook, and storytelling. I want to start this section with the warning that, no doubt in some respects like television and Facebook, narrative

14. Bernard Stiegler, For a New Critique of Political Economy, Cambridge, Polity (2009) 2010, pp7-8, henceforth $F N C$ in the text. 
15. Although Stiegler does not use Marx's word subsumption, he offers a related analysis as part of his 'new critique'. On subsumption see Marx Capital Vol.1, op.cit., pp10191045.

16. David Fincher (director), The Social Network, USA, 2010. is pharmacological in that it can both shape minds and educate just as much as it may capture and contain thinking. Indeed, in a consequence Stiegler perhaps must omit, it may be ineffective, disorganised, and effectively ignored by the child: 'Granny, what big teeth you have!' Let us note the suggestion that audiences can become immune to the charms of a story, can tune in and out, and can leave it unresolved, or 'to be continued'. There is perhaps a dialectic here: the distraction of attention may actually be a refined and critical inattention.

Stiegler however is clear that the family scene has been subsumed, ${ }^{15}$ and this subsumption proceeds via 'progressively liquidated life skills in an industrial economy based on programming industries' (TC, p128):

the process of capturing public attention is handled by service industries, cultural industries and programs synchronizing individuals' activities into mass behaviors motivated by business plans ... Service industries that utilize psychopower no longer sell anything to a population that thus no longer needs to pay anything: people, having abdicated their majority without being conscious of it, 'give themselves' to these industries, or rather, the industries capture them as 'available brain time' psychopower enterprises to sell young adults on the market $(T C, \mathrm{p} 38)$

Apart from the fact that we do mostly pay for television, mobile phones, Macbooks ${ }^{\mathrm{TM}}$, internet connections, printer ink and cinema tickets to see The Social Network, ${ }^{16}$ the capture of - the gift of - available brain-time through instruments of psychopower is a crucial concept that relates, almost inversely, to the process of proletarianisation as deskilling that comes with the mass industrialisation of human ability and capacities. The notion of abstract labour power is here generalised, even if it is still unclear if I am really fully involved in ceding my brain-time as abstract brainpower calculated as an aggregate of labour across the entire social field - if brain-time, attention, or psychopower is to be harvested, then we should perhaps then talk of cloud labour in the same way we talk of cloud computing.

There is also the question of the degree to which, outside of the strict wage relation, brain-time is more or less constitutive of labour capacity today. Is brainpower tapped through unpaid work more than was the case previously when it was possible to talk of reproduction, community, morality and nation? Admittedly in the European bourgeois family, unwaged supportive, attentive and reproductive work was even more exclusively the unpaid work of women; community as attention to neighbourliness sustained the social life of the workforce; moralism was attentive, whether derived from tabloid media or religious precept; and citizenship/nationalism contributed to the coherence of a population willing to sacrifice itself for abstract ideas. These are all sustaining unwaged contributions to capital that also have their intellectual - brain-time - components. It may be that the originality of contemporary 
capitalism, and of the new critique of political economy, consists in being able to replace these old terms with the new language of service, culture and business plan, which frankly does not seem all that new after all.

But it is the transformations that are our concern, and among the greatest of these in relation to 'proletarianisation' is cretinisation, and perhaps the theme most relevant for today in the face of widespread cuts to education budgets, welfare, migration - international students - libraries, the Arts, terms and conditions of work and school/training curriculum content, is the retooling of education and knowledge:

Given that, today, mechanized understanding and the schematism of the cultural industries have converged, this education system, a product of the nineteenth century but inspired by the seventeenth and eighteenth as a structure for the interiorization of prostheses constructing the history of ideas and knowledge and of the We insofar as universal consciousness disseminated national stories - this educational system is itself now being questioned within the technical system as it (and, along with it, consciousness) transforms into the global mnemotechnical industrial system (TT3, p146, emphasis in the original).

It is Stiegler's argument that 'the public education systems and training programs instituted in the 1880 s have been slowly but irresistibly ruined by mass media and the programming industries, in particular by television' (TC, p52). This ruination has been a 'self-labotimisation', replacing public opinion with the audience (TC, p53) as if it were undoing the social contract worked out to fit training to capital with an unreasoned and unthoughtthrough, always-on attention to gadgets and devices, that themselves are transforming the way we teach, the place of the University and the School, and the very idea of instruction. We might note that computer programs do come with manuals, but it is perhaps better to learn how they work intuitively, exploring the drop down menus etc. ${ }^{17}$ Stiegler's lament however is that professors and 'all those responsible for the transmission of knowledge' have 'become marginal at best' or 'completely stripped of their role' (TT3, p150). This belongs to 'acceleration' 18 and a view of 'school as a kind of playground for babysitting' (TT3, p150). In this fairy tale, the professor is a 'perpetual student' (TT3, p149), trapped in a Peter Pan scenario. In actuality, it is not 'only educational institutions that can provide historical consciousness to collective consciousness' (TT3, p147, emphasis in the original). Here the danger is of producing a fantasy vanguardism without a vanguard, or Party, to accompany a Kantianism without transcendental subject - in the end an echo of mechanised rote learning when things are, we may hope, more complicated.

The analysis of why education has a place as pharmaka is well known. 'The power exercised by the programming industries' psychotechnologies today ruins all the benefits of [the] revolution of (inherited) intelligence' accelerated

17. $\mathrm{RTFM}=$ 'read the fucking manual', thanks to Steve Nugent.

18. Ibid., p151. I have made a critique of speed hype in the Derrida chapters of my Bad Marxism: Capitalism and Cultural Studies, London, Pluto Press, 2004. 
by industrialisation and its need to elevate the population through public education (TC, p60). No doubt this is an astute interpretation of the ways education is tied through printing - as tertiary retention, explained below - to the industrial-commercial system, but the argument of 'ruination' sounds strangely familiar from elite educational circles in the UK. Lamentations that the kids don't pay attention anymore, that standards have slipped, of a lack of respect for elders and a general shallowness of culture is an attitude that usually does not need references to Ancient Greece or children's fantasy to back it up. The 'ruination' thesis also sounds familiar in that it ascribes power to the technologies themselves, rather than the uses made of them. Marketisation of technology requires a market structure that was the core material component of industrial training. Marx's comments on training in chapter 16 of Capital seem highly relevant here, as we will soon see.

For Stiegler, the key problem is the 'ruining of all sense of responsibility' (TC, p53), lost through television's destruction of the ways we foster attention through inter-generational relations. However much I agree this is a part of the equation, I am sceptical that the schools, once called ideological state apparatuses for good reason, are the last bastion in a struggle against entrapment by Microsoft and the like. Even though there are grounds on which to oppose monopoly, the blanket condemnation does not seem warranted, television is condemned where, for example, the failure of left organisation should perhaps also be the focus - why is the Left so bad at TV? As Stiegler has also said, not every capture of attention need be a shortcircuit. Since when did a progressive politics think that the systems of public opinion formation that emerged from hierarchical education, especially in France for example, were not something with which to do away? Even if the violence of television, programming and education may be excessive, a new equilibrium seems optimistic - the 'disequilibrium' of the 'reign of television' for Stiegler 'tends to diminish everything that might be elevated, crushing and literally wiping out all other social organisation of transmission and, of course, first of all the family and the school' (Decadence, p47). Yet it is not only turning off the TV and going back to school that will save us, and it should be underscored that this is not all that Stiegler recommends.

When television replaces literacy, Stiegler's model of writing appears both more detailed and narrower than that of his mentor Derrida. This has profound implications when he describes post-WW2 audio-visual programming as having retooled the educational developmental disciplinary structure of the schools. The consequent "psychological, affective, cultural, economic and social disaster'(TC, p58) has introduced inter-generational disconnect, insecurity and delinquency as well as the marketing-driven removal of youth from the educational system so as to adapt them for immediate market needs. Here the valorisation of a European education is posited in association with both writing and French colonialism - unfortunately not yet taking into account the experience of, and research upon, the colonial 
subjects who also received that literacy and education. This dictates a closer inspection of Stiegler's notion of writing as grammatisation.

\section{MACHINE GRAMMAR}

In this context, we can think of writing as a technology which breaks the flow of language into discrete elements. This too has a close relation to the idea of proletarianisation where 'discretisation' invades the gestures of workers and these are grammafied for automatic production in the machine. As we have seen, one component of Marx and Engels' notion of proletarianisation is that it entails a process of losing knowledge and production skills during their incorporation into the machines of industrial production. For Stiegler, this entails the proletarianisation of participation in the technical history of memory, a 'grammatisation' process that is situated between an amnesic and hypomnesic memory, that leaves the individual abstracted or alienated from the milieu of technical apparatuses that shape memory, indeed being. The machine works the worker, as Marx would say over and over - the worker is an 'appendage'. ${ }^{19}$ But now, the machine is the individual, in a kind of 'short-circuit' (TC, p38) of the workers who have together developed and innovated the technical milieu of their work, tools and systems. The creative agents of the milieu become the subjects of it, even objects. Within a system of tools and knowledges, workers become machinery with a cost, including cost of maintenance, repair and scrapping, that is separated from any selfconstituting grasp. This occurs at all levels of the social order.

Stiegler then makes an important intervention suggesting that it is not just knowledge and skills but thinking that has been smashed. We have been made to un-think by separations, dissociation, grammar. This might be reformulated in Marxist phrasing as the machines think us - the General Intellect becomes an oppressive collective will, alienated from us - which of course we need to sublate. But Stiegler does not concede this to Marx, and says 'Marx still does not properly analyze the accumulation of intellectual capital that has today become an essential issue, and more generally he ignores what I call artificial retention' (TT3, p85, emphasis in the original). It seems Stiegler confines intellectual capital - not General Intellect - to retentional devices, whereas when Marx says the machine works the worker, many times throughout his later work, it is clear General Intellect is both a continuation of the deskilling entailed in the industrial division of labour, but extending also to bourgeois ideas and ruling class circles more generally. In the Daily Tribune of 1861 he writes, 'the progressive division of labor has, to a certain extent, emasculated the general intellect of the middle-class men [and women] by the circumscription of all their energies and mental faculties within the narrow spheres of their mercantile, industrial and professional concerns'.$^{20}$ The point is that these are the spheres of accounting and management, and a continuation, impacted to a 'certain extent', now increasing. It is a matter of 'degrees':

20. Karl Marx The New-York Daily Tribune, 21 October 1861. 
21. Karl Marx

Grundrisse, http:// www.marxists. org/archive/marx/ works/1857/ grundrisse/ch 14. htm - accessed 5 December 2008.

22. Bernard Stiegler, 'Nanomutations, Hypomnemata and Grammatization' from http:// arsindustrialis.org/ node/2937 - accessed 5 November 2010.
The development of fixed capital indicates to what degree general social knowledge has become a direct force of production, and to what degree, hence, the conditions of the process of social life itself have come under the control of the general intellect and been transformed in accordance with it. ${ }^{21}$

This justly famous passage by Marx is to be updated with a 'critique' (Decadence, p41) that then becomes Stiegler's description of the new:

Now a few years into this 21 st century, which will be the century of nanotechnologies and which will see unheard of relations between technics, science and desire, the crucial question of what links and distinguishes power, knowledge and the will, i.e., the question of what can, at times, set these infinitives into oppositions, composing them at the same time, by posing them together, this question which, more profoundly and par excellence is the problem of thought and its ass's skin - as though it diagrammed the mechanism of that stupidity Deleuze called 'transcendental' - this question is a problem for us, so much so as to appear to have become unthinkable. ${ }^{22}$

Stiegler uses the term 'mnemotechnical retention' to refer to the ways memory and experience are exteriorised. This 'tertiary' layer of retention exists as material culture into which we are born, into a world not of our own making so to speak, though as the exteriorisation and spatialisation of individual time becoming collective time, 'tertiary retention is an original exteriorization of mind' ( $F N C$, p9). Buildings and writing systems, languages and machines, and the industrial revolution can all be understood in these terms. In Stiegler's argument the gestures that are, in these systems, increasingly reproduced as tertiary retention are either discretised or subject to grammatisation - and this is 'the process of proletarianisation described by Marx and Engels in the Communist Manifesto' (FNC, p11).

It is Stiegler's view that new retention technologies, like audio-visual recording, unavailable to Marx, constitute new forms of proletarianisation. I am convinced that this is important, but think we should ask if Marx did not already anticipate this, as well as whether this over-values the 'new' in new media. We should, instead, ask where the place of agency resides in front of machines, including television, but also education, and 'psychotechnology', and whether, perhaps, the 'proletariat' might be less atomised than here implied, and also more or less still caught up in a struggle with the market. Stiegler rightly warns that the 'shameful' charge of economism should not mean the political must be purged of economic questions, nor should it mean the economic can be ignored in philosophy, nor that urgent questioning be left merely to some 'obsessive relation' of erudite devotion to philosophical economic texts of the past - let us not be too attached to new culturalist 
texts also. The economic interests of the new media domains might also be subject to some older economic questions. The economies of the market and the industrial imperative that compels all to adopt the bourgeois mode of production, and thus that which 'sinks' more and more of social life into the proletariat, might be relevant once again.

As a counter charge to 'economism', we might also wonder if the constant recourse to a largely uncritical fascination with new media isn't also a mirror image of such economism, this time as capitulation to the techno-consumerist agenda of the gadget corporations. An obsessive relation to the technologies of inscription that have seemingly ubiquitous sway. There is room to question the imperative built into talk of adoption as a family drama. Again agency or the political in terms of collective organisation and resistance needs to be thought together with technology (retentions) and economics. This is where it is interesting to hear Derrida ask the mock-serious question: what if [mummydaddy] Freud had email? He suggests that this would change everything, that 'above all, email' transforms 'the entire public and private space of humanity'. ${ }^{23}$ Well, what if Marx had Wordpress, access to CCTV, Skype and Ebay? Wasn't it Marx who said, with Engels, that bourgeois capital offers 'rapid improvement of all instruments of production' and 'immensely facilitated means of communication'. ${ }^{24}$ The translation of immensely facilitated from the German 'unendlich erleichterten' ${ }^{25}$ might be better rendered as 'infinite release' if we take into account that Marx has in mind not only communications in the sense of letters and telegraph, but a 'feverish velocity' or 'fieberhaften Geschwindigkeit', ${ }^{26}$ of communication as transport and transportation by way of 'a system of river steamers, railways, ocean steamers and telegraphs' that goes beyond anything the manufacturing era could imagine. ${ }^{27}$

So, of course we should think not just of writing machines, but it seems quite late in the day to be catching up with the realisation that writing orders the possible. Nevertheless, Stiegler sees through words:

I call 'grammatization' the process whereby the flux and flow networking our existences become discreet elements: writing is thus, as the breaking into discreet elements of the flux of speech (let us invent the word "discretization" for this possibility), a stage in grammatization. Now, the process of grammatization, with the dawn of the industrial revolution, suddenly surpasses the sphere of language - one wants to say that the same thing happened to the sphere of logos - and invades the sphere of the body: first and foremost, the gestures of workers, which are discredited, devalued in view of their automatic reproduction - while at the same time the machines and apparatuses of reproducibilities of the visible and the audible appear on the scene. ${ }^{28}$

Writing here feeds off proletarianisation in so far as this is the process by which skills and ways of doing things are transformed by technological

23. Jacques Derrida, Archive Fever, Chicago, University of Chicago Press, (1995) 1996, p17.

24. Marx and Engels, Manifesto, op. cit., p84.

25. Karl Marx and Friedrich Engels, Manifest Der Kommunistischen Partei, Berlin, Dietz Verlag, (1848) 1970, p47.

26. Karl Marx, Das Kapital, Erste Band, Berlin, Dietz Verlag (1867) 1975, p405.

27. Marx, Capital Vol. 1, op. cit., p506.

28. Stiegler, 'Nanomutations', op. cit. 
29. The smart money might want to be placed on a technological integration of voice box and computational interface, bypassing writing by hand, typing and even vocalisation and diction. This must be experienced as a loss, just as was relative weightlessness when the first amphibians emerged from the buoyant three dimensionality of the sea onto a gravityheavy cartography (it is birds who refused to accept this loss, and dolphins perhaps berate us for leaving).

30. Marx, Capital Vol.1, p644.

31. Ibid., p643-4. developments, for example, with the onset of automated writing tools the skill of handwriting recedes into a past, just as is likely the skill of typing will cede way to voice recognition - and the carpel tunnel syndrome I have developed upon using my Ipad only hastens this evolution. Indeed, carpel tunnel is an indication of the future in the same way that sore feet might have been a consequence of the loss of hunting grounds and the sedentarisation of agricultural society. This is a pretty lame routine and the General Intellect is retentional in a more profound way. ${ }^{29}$ The planned farming day is a grammatisation of the walk-all-day lifestyle of the hunter-gatherer nomad scaling up from this gets us to market to market (jiggidy jig) and soon after industrial and neo-liberal capitalism.

\section{COMPOSITE WORKER}

The key point here is that it is not the - fetishised, digital - convergence of things that matters so much as the convergence - as proletarianised labour powers - of people. Long ago Marx had already noted that industrial capital colonises the brain. His work on cooperation stands as evidence. In chapter 16 of Capital Volume 1, Marx makes a distinction between productive labour and 'subordinate functions' that should give educationalists pause:

a schoolmaster is a productive labourer when, in addition to belabouring the heads of his pupils, he works himself into the ground to enrich the owner of the school. That the latter has laid out his capital in a teaching factory, instead of in a sausage factory, makes no difference to the relation. ${ }^{30}$

This is crucial for discussion of the 'teaching factory', where academics add capacity and help reproduce the productive labourers of the future (their students), while oftentimes also producing a 'surplus' through fees, consultancy, research contracts and the like. This opens a set of strategic problems in need of close examination, since the narrative here is never innocent - and again I write in a context where massive funding cuts to the University sector join the raft of general neo-liberal cutbacks across the sectors. The wider point, however, is that Marx is making no strict distinction between manual labour and brain labour, between 'head and hand'. It is 'the co-operative character of the labour process' that turns the labourer into an 'organ of the collective labourer, and to perform one of its subordinate functions. ${ }^{31}$ Stiegler's talk of grammatisation is the continuation of the process that entails loss of knowledge and know-how that are today transformed into 'technologies and industry' via the 'cognitive relational and cultural technologies' (Decadence, p22) under what he calls 'hypersynchronised' (p23) and 'hyperindustrial capitalism' (p130). This is a refined case of where Marx writes: 'the means of production are ... changed into means for the absorption of the labour of others. It is no longer the worker who employs the means of production, 
but the means of production that employ the worker' ${ }^{32}$ Proletarianisation at the level of simple division of labour is only step one of the development of a systematic alienation, as elaborated also by Marx in the latter chapters of Capital. Stiegler announces,

this grammatization of all the aspects of the human behaviour (intellection, motor functions and perception) leads to what is known today as cognitive capitalism. [And that] ...this cognitive capitalism is also a cultural capitalism, which I have analysed elsewhere as a hyperindustrial cognitive capitalism. ${ }^{33}$

Here, I am not sure we have moved much further than chapter 25 of Capital. The machines work us, they employ us - they think us too. And with a hint at another important aspect of Marx's commentary on proletarianisation, this implies a conscious struggle. Where Marx writes that 'the worker exists to satisfy the need of the existing values for valorization', an alternative possibility would have 'objective wealth' made to 'satisfy the worker's own need for development' and this is then articulated in terms of head and hand. Echoing Feuerbach, Marx writes 'just as man [sic] is governed, in religion, by the products of his[her] own brain, so, in capitalist production, [s] he is governed by the products of [her] his own hand'. ${ }^{34}$ It is here in the intersection of Stiegler and Marx that there might be reason to work again at the writing machine that renders proletariatisation into prose.

In this domain, un-thinking must be challenged as discretisation infects even the way we un-think education, training, preparation for work, television, entertainment, family play, reproduction - all parts of life subsumed under commoditisation. Thinking of the teaching factory, we might here also wonder at the role of academic and other written modalities of surveillance and administration. The intellectual mechanisation that is reduced to governmentality, the management of work and non-work - the lumpenproletariat, the reserve army of labour - the training programs and reproduction are also the alienated provenance of this separation of mind and hand. A vast integrated convoluted cognitive machinery, of which the culture industry is not merely a covering apparatus and component. Training and shopping and recorded music: never co-constituted in alienated thinking; never components of a co-operative grammar, to come ...

Is it unthinkable to undo this nexus of head and hand, finger and dial, university and state, intellect and war, scholarship and capital? Stiegler has opened up a possible avenue of inquiry that tackles such problems, and where we are capable of noting also that attention marketing requires complicit academic agents, this is of course a dangerous - pharmaka - terrain. Attentionmarketing requires product review, exclusivity/exclusion and an undisclosed delusional god-complex that would have the critical critic declared as the only one able to see the proclamations of self-awareness that would not
32. Marx, Capital, op. cit., p425.

33. Bernard Stiegler, 'Individuation, hypomnemata and grammatization' http://www.scribd. com/doc/19327979/ Bernard-StieglerIndividuationHypomnemataion - accessed 5

November 2010

34. Marx, Capital Vol. 1, p772. A hilarious footnote here has Marx quoting Von Thünen asking how the worker had moved from 'being the master of capital - as its creator - to its slave'. Marx says it is to Von Thünen's credit that he asks the question, but that his 'answer is simply childish'. 
reflect on institutional or industry positioning. Stiegler can hardly be said to ignore the escalating context that would link the family and play to the school and training, to the cultural industries and to the global financial markets, but, although implicit, it seems such connections are not consistently or explicitly related to Marx and Engels' still wider notion of proletarianisation as conscious struggle. Nevertheless, he does underline the connection where the financial or marketised context is one in which:

our existences are now deeply implicated in networks of specialized technolological information of which we are largely (unavoidably?) ignorant, yet which force us to delegate our futures to the firms and agencies that then delegate them to markets. This is the context in which the service economy 'produces' dissociation - the destruction of associational media through development of psychotechnologies eradicating psychic and social faculties (particularly attention), replacing them with automata stripped of any reinteriorization process; that is, without critique, and thus without responsibility (TC, p134).

\section{CRETINISATION}

To change the tone of this narrative somewhat, this penultimate section explores more explicit biographical and political investments in time. The move to consider attention marketing emerges, I argue, from autobiographicaltheoretical thinking in Stiegler's shortest book, Acting Out. Stiegler describes his experience of incarceration in prison in curious terms: incarceration entailed a separation from the world that allowed him to contemplate his milieu 'as does a flying fish, above his element' ( $A O, \mathrm{p} 15)$. Certainly not your average jailbird, Stiegler plunged into a philosophical menagerie, with only animals for company. Elsewhere he talks of a 'flock of parrots', meaning those who 'ape' the chatter of digital ideology (Decadence, p5). When he writes of the radio, television, internet and audiovisual electronic technologies that engender repetitive behaviour, this is a 'herd' in Nietzsche's sense ( $A O, \mathrm{p} 48$, my emphasis) or 'becoming herdish' (Decadence, p53, 56). And throughout Technics and Time there is an eagle picking away at Prometheus' liver, ticking

35. Bernard Stiegler, Technics and Time 1: The Fault of Epimetheus, Stanford, Stanford University Press, (1994) 1998, p202. away the recurrent hours. ${ }^{35}$

Animals and time become interesting when Stiegler suggests that the crisis of capitalism is a collapse that occurs through short termism, with the time of knowledge and of investment erased, and proletarianization of retention meaning an extensive loss of knowledge. Capital is 'a dynamic system threatened by a limit that would be reached if the bearish tendency to which the very functioning of the profit rate gives rise were to achieve completion' $(F N C$, $\mathrm{p} 75$, my emphasis). These are not bears asleep in caves, but rather short-term rogue traders - metaphorically beastly animals roaming the financial woods, only occasionally in hibernation. But every time the bear appears Stiegler 
also tends to tell us about something of which Marx was 'unaware' $(F N C$, p88) - in this case marketing, but in others it is always a new and unforeseen response of capital in America and so forth. For Stiegler, the proletarianised consumer's libidinal energy is a new energy that Marx could not anticipate, even where Marx discusses consumption as productive (Decadence, p64). For Stiegler the capitalist system is bearish or fictitiously speculative, and Marx failed to take this 'fully into account' (FNC, p89). The key to Stiegler's thinking here is that the rate of profit no longer has to do with a credit crisis, but is rather the consequence of a culture of corruption, where capital becomes 'Mafia-esque' and a dominant, and Freud-esque, 'consumption-drive' is no longer to be understood in relation to the equation $\mathrm{P}$ equals surplus over constant and variable cost of production, that is 'a profit that no longer bears any relation to the profit rate calculated by ...' Marx (FNC, p92). This form of capitalism 'cannot be thought with Marxist concepts alone' (p87). The new economy associates the present milieu of capitalism with a stupidity that is the proletarianisation of the nervous system.

Stiegler's discussion of stupidity is key to his understanding of the contemporary psychotechnological predicament and gives an insight into what is at stake in the parameters he sets. There are three questions he poses in the 'battle for intelligence':

The first [question] requires asking oneself about the intelligence that is required to ask about intelligence.

The second consists of knowing why it is necessary to engage in the battle for intelligence.

The third and last requirement for any contemporary battle of and for intelligence in the struggle of and with technologies of intelligence, in which psychotechnologies that might produce stupidity by destroying attention transform into the technologies of an individual and collective intelligence whose aim is to constitute $a$ social (political) apparatus for unifying all social apparatuses, the economic, juridical, educational, scientific, artistic and cultural (as well as the medical) and those focusing on society's protection, such as internal and external security, and so on (TC, p30-31).

The last of these is not expressed as a question so much as a problem area, but the iteration is particularly interesting - the repetition of 'of and for', 'of and with' and the list and commas and after the clause, 'and so on'. It might be suggested that this cascade indicates a point of tension, and this precisely in relation to security, society's protection, which is also to say, in contemporary terms, the consequences of the war of terror. Or might we say, the war 'of and for, of and with, and, and' terror.

We are not, however, talking here of the kind of political mobilisation Marx 
36. Stiegler, in Derrida and Stiegler, op. cit., p88-9. and Engels had in mind. Cretinisation and an 'auto-cretinising' of social life produced by the unregulated power of the media monopolies is, strangely, 'also and indeed first of all a question of the responsibility of our political representatives, above all those who are not simply political representatives but have executive power' (TC, p90). Stiegler then calls upon Sarkozy. The problem is not the mute leadership, which is of course in the pay of capital as the executive class of the bourgeoisie, any more than it is the irresponsibility of allegedly patronising intellectuals who think that the masses are no more than dupes, while being equally duped by the trappings of power themselves. Again, 'the misuse of psychotechnologies can have catastrophic effects on juvenile consciousness. Our political representatives, particularly those in power, are thus faced with exceptional responsibilities' (TC, p190). Disregarding any 'cognitive overflow syndrome' or attention deficit, Stiegler then again calls upon Sarkozy, this time alongside Al Gore, to fight against psychopower (TC, p191).

It is here that psychopower is to be placed 'under constraints' (TC, p191), yet these constraints remain quite abstract. I would say this tends towards impotence when Stiegler suggests that the 'surrender to machines' leads to a 'short-circuiting of psychosocial transindividuation - of the generations as well as social classes and territory' $(T C, \mathrm{p} 152)$. It is always dangerous to locate problems in the mixed metaphors of cartography and show jumping, but Stiegler does not think it impossible to 'correct our course' even if 'many obstacles stand in our way: in the first place, a veritable conspiracy of imbeciles' which is also a 'conspiracy of inattention' (TC, p87). This correction, which is a 'weighty task' and 'par excellence today's political responsibility' is something that 'belongs firstly to those whom one calls "intellectuals" ... thinkers, savants, artists, philosophers' (Decadence, p145).

It may seem stupid to refuse to concede, but as teaching - from cradle, to school, to factory or office - is about paying attention, endlessly, might it not be worth the experimental suggestion that there could be another kind of organisation and another kind of time? Let us take our time with this. A non-clock time that tampered with the expectations of clockwork and machines, and thereby with attention, might at least not be so quick to make the equation of long-circuit as good, short-circuit as bad. For Stiegler, time 'is completely singular' and with television 'one actually has the feeling that it is impossible to stop' ${ }^{36}$ The eagle pecking daily at Prometheus's liver is the carrion beast of clock regulation. As has often been pointed out, the clock has been a device used to trick workers into conceding their labour power, and now we can see also their 'brain time', to the capitalist for less than its value. Against this is the intentionally stupid insistence that it might be possible to imagine that there are many and multiple nows, simultaneous short-circuits and long-circuits, multiplying, sometimes good, sometimes bad. This may even be called dialectics - co-constituting and interactive, perhaps sometimes interchangeable, or reversible, circuits of time, and we - as subjectivities, trans- 
individuations of individual workers - are unable to access this abundance of time except as unthinkable, counterfactual, delinquent provocation. We perhaps approximate this thinking in the mad chaos of co-operation, and even in solidarity - workers of the world unite! - or perhaps in the planned economy or in hope for the future. Whatever the case, we do not yet think this together, as Marx, I think, suggests we do.

It should be clear I think that Marx, in Capital Volume $2,{ }^{37}$ is on a somewhat different track than Stiegler, in that he thinks multiple times of circulation and simultaneous circuits - many and multiple circuits - of capitalism - not just production, circulation and consumption, as these too are a multiple dialectic. His cognition is transindividual for sure, but as an internationalist, systemic and multi-located, integrated, uneven, complicated, diversified in unity, thinking of the world - where I am not separate, but connected, through choice, even if I cannot grasp this as yet. It is just here we might try to think - from now - that which links and distinguishes a political struggle over power, knowledge and will.

Is Stiegler more worried about time than he should be? Taking care would require long-circuits of attention such as that which Dan Ross usefully illustrates with reference to the formation of taste as opposed to the satisfaction of hunger. ${ }^{38}$ The trouble is that this entails a polarisation of hunger and taste appreciation that may not stand up in practice. The forms of labour that prevail in contemporary capitalism are many and varied, often mediated no doubt, and variously subject to interruption, relay and redoublings. What can be asserted is that there is now a trend towards more diverse forms of family, community and association than could be known in the bourgeois European family of nineteenth century industrial Britain, and probably this is a good thing. But I am not sure that the circuits here are thought through as carefully as they might be.

Let this be made clear: for Stiegler, a long-circuit means the use of technical prostheses to produce transindividual knowledge and desire, whereas shortcircuit refers to the passive fulfilment of drives such as vigilance. ${ }^{39}$ There is no guarantee that long or deep attention doesn't also hand us over to convergence and hyper synchronised grammatical microtechnology. If proletarianisation extends to all, not just the working class, because consumption became a necessary component of cultural control - as Adorno understood - so as to respond to contradictions in capital - that Marx did not understand, says Stiegler - and this today threatens destruction, then we are in trouble if only 'intellectuals' can save us with long division. I am concerned that the anxiety expressed in the face of a consumerist, and indeed the theorist's, scramble to respond to the convergence of new media has elevated a conception of reproduction of memory and meaning, located and alienated in technologies of tertiary retention, while relegating possibilities that do not rely upon calling on Sarkozy or 'intellectuals' for political representation. There is a question here - 'impotence' (Decadence, p60) - that renders the scene decadent when
37. Karl Marx, Capital Volume 2, Moscow, Progress Publishers, (1893) 1956.

38. Dan Ross, 'Politics and Aesthetics, or, Transformations of Aristotle in Bernard Stiegler' Transformations, 17, (2010): 3 .

39. I thank Inigo Wilkins for helping me clarify this distinction, though I think the clarification reduces and polarises. Bernard Stiegler himself has been a Visiting Professor in the Centre for Cultural Studies at Goldsmiths for the past three years, and his visits occasioned much engaged discussion of his work. 
40. Paul Virilio, Speed and Politics, New York, Semiotext(e), 1977.

41. Derrida, Archive Fever, op. cit. perhaps we should look more closely at the kind of family and convergence we might want to adopt or which is to hand, in Heidegger's sense. For example, Stiegler does not address reproductive labour, or cohesive work for moral(ity), community or nation, insofar as these too are collective efforts and many timed narrations. The rather undifferentiated concept of the long-circuit does not do enough to get at this. Long and durable 'duration' replaced by the new means a loss that it would be tempting to caricature as a fear of senile very late capitalism: queuing for Medicare and pensions while the shaking invisible hand of the market grips the virtual zimmer frame of instability. Can a more nuanced model of time, labour and technology be released on the back of Stiegler's analysis?

There are several symptoms that indicate such - pharmacological treatment in theoretical discussions within the academy. For example, the speed-hype that exercises the likes of Paul Virilio ${ }^{40}$ and Derrida; ${ }^{41}$ let us call these acceleration-valorisation theorists, and those that anticipate 'cognitive overload', a kind of fear of information-glut. Both positions line up alongside a somewhat senile cretinisation that would merely gawk at the discombobulation of very late capitalism, continually checking to see if it has its bus-pass, if its papers are in order, if it has not lost its keys or left the gas on - there is a suggestion in all this that the mode of production now passing is a permanent state of decay in those that would hang on for grim death should be prised off the handle - or steering wheel, rudder, or anchor? Does it not sound like anxiety about youth when we read 'the central question for the media world' is now that of 'control of youth's psychic and social apparatuses from the youngest age, despite its destruction of the intergenerational circuitry'? (TC, p132)

\section{FOR A NEW CRITIQUE}

The work of forming attention undertaken by the family, the school, the totality of teaching and cultural institutions, and all the apparatuses of 'spiritual value' (beginning with academic apparatuses) is systematically undone by the effort to produce a consumer stripped of the ability to be autonomous either morally or cognitively - to have consciousness as free will, without which there can be no 'science' that is not ruinous (TC, p184).

Stiegler's ruination is located in the schools and the family but these spaces are not thought through in terms of the politics of proletarianisation as conceived by Marx to stem from the 'sinking' of more and more workers into the wage relation, and even - we have work to do here to address an imbalance - reproductive labour that itself becomes proletarianised. It is certainly the case that the production of consumers is at play here, but a survey might find forms of proletarian work that might still need attention - sex work, cleaning, bringing up children: all industrialised in the service and affective 
economy. ${ }^{42}$ Reproduction, community, morality and citizenship are four key areas of contribution to long-term social and productive life that remain largely outside the calculus of waged labour. That these areas of contribution are made over time and rendered increasingly visible through attachments to commodities is no surprise. The washing machine or cooker, the clothing or songs of an ethnic identity, even where hybridised, the daily newspaper or a bookshelf full of improving literature or a valid passport with visa entry stamp are all calculable commodity forms, the disciplining of life through a monetarisation that we cannot not want acknowledged. As Stiegler writes,

there is nothing inevitable requiring that time (attention) be captured and monopolized in young brains by marketing, nor that this process should result in the systematic deprivation of consciousness, to the point that it might become literally impossible to (re)educate those organologically conditioned brains that have become prone to incivility or delinquency. Nor is it inevitable that older brains, subject to the same conditions, should find themselves deprived of all responsibility; that is, of their capacity to oppose such conditions (TC, p35, my emphasis).

This is why the discussion of education was important. Stiegler does not think it impossible to imagine 'an alternative model' where the 'tools required for a life in hyperindustrial societies' might emerge via an 'appropriate [adoptive] education system' - though he notes that this 'might be a utopian vision ... completing the process of what I have called generalized proletarianization' (TC, p97).

There is the possibility of going further here, to proletarianise it all, and taking up Marx's nuanced consideration of proletarianisation in a wider sense, suggesting that what is called incivility and delinquency are indeed the opposition, or at least a part of, and beginning of, an organised resistance to that which would reduce all of life to marketing controls. Consider all the ways the family, nation, migration, economy - privatised, end of welfare, education - utilitarian, commoditised - and war, including urban security and terror anxiety, have transformed the space of bourgeois society since the advent of neoliberal capitalism. With the public debate, such as it is, focused on parenting and a decline of respect for old family values, in Britain at least, then a Marxist interpretation of the present crisis should not stop with a diagnosis of ruin. The recognition of delinquency and incivility are not enough, and we may need rather more delinquents, and considerable civil unrest, before a revolutionary call to attention gains ground. The danger of the attention-capture diagnosis of the 'current politics' renders the masses passive too readily and ignores the Marxist content of proletarianisation as originally set out by Marx and Engels: the advent of a political struggle on the way towards a new world where 'the free development of each is the condition for the free development of all'. ${ }^{43}$
42. What is difficult here is that the theoretical charge that offers a focus upon service and affect (trinketisation) both recognises that this alienation into objects and objectification of relations is damaging, but also necessarily wishes to calculate the unpaid work entailed, thus aiding marketisation. It wants to both condemn reduction to a calculus and applaud. Crucial here for me is the work of comrade Camille Barbagallo and others in the group Plan C. http:// www.weareplanc.org.
43. Marx and Engels, op. cit., p70. 
So when Stiegler calls for a new critique of political economy, as we have seen, he does this with a judgemental and simple notion of time and without a concept of praxis or revolutionary party activism. In Technics and Time, Taking Care, For a New Critique of Political Economy and The Decadence of Industrial Democracies at least, he has very little to say about class or social conflict, nor ventures any effort to understand how class composition must be updated in ways that can also learn from Marx and the notion of the General Intellect which already maps out the composite worker. Stiegler's impressively nuanced analysis of digital retention shows how writing is part of the new composite class formation of a 'new' proletariat who are also media literate. Here where universal education was the nineteenth Century deal, we are now collectivised through gadgets. But there is no appreciation of how the proletarianised consumer must and does confront these gadgets as machines also in class terms.

Stiegler and Ars Industrialis update the notion of proletarianisation for contemporary times but in doing so they underplay the two key dimensions of Marx and Engels' conception that follow on from step one. In focussing on loss of skill and knowledge, ceded to the televisual and information systems, the immiseration that results from 'sinking' into the exploitation of waged labour - nowadays also brain-labour - and the mobilisations resultant from such abjection are minimised or ignored. In this context, the stupidity of delinquents is condemned and childishness, bearishness misconstrued. Does Stiegler not see that stupidity too can be pharmacological? The point is that Marx's notion of proletarianisation has three components and very often the third is left aside in the too hard basket. The work of labour that creates community - transindividuation, is also done in mediated form and perhaps even through ruinous modes of engagement with media and work formats. The immediate circuits may involve unpaid labour, brain-power, attention or being often captured, often exploited, often disassociated, but is also often expended in exuberant, rampant, excessive and - is it so unthinkable - proto-revolutionary ways. Mao said, apropos the 'riff raff', that he does not agree with those who claim the revolting peasants go too far when they band together to destroy the bourgeoisie do not share his view. He praises

44. Mao Tse-Tung 'The Movement of the Riff Raff', Selected Works Volume 1 , Peking, Foreign Languages Press, 1975 , pp29-30 their action in the circumstances, and will not criticise them by muttering 'it is terrible', as so many others do. ${ }^{44}$

Stiegler's argument is that the televisual system captures the attention of youth and destroys the long-circuit of care of family and education. It is certainly true that transformations are underway, but it may be that we need to think of the durations of transformation with an understanding of time, engagement and politics that offers a still longer conception of duration, or a multiple and non-linear notion of time. There may be concurrent longercircuits of class composition that are relevant here, or even multiple-circuits of engagement and transformation that can be more subtly evaluated - as not necessarily 'too bad' or 'all good'. Stiegler does open up these directions 
even where he does not follow the Marx of volumes two and three of Capital and of The Poverty of Philosophy ${ }^{45}$ which might extend his argument.

Marx's thinking on the circuits of capital might suggest dialectical readings of several non-commensurate, simultaneous circuits of finance/credit, production and consumption - division one and division two, productive consumption, credit, the tendential decline - that could then be brought to the discussion of family and education to complicate our evaluations. If there are several possible long and short circuits of, for example, ruin, riff raff, or of televisual/ cultural industry inattention, then capture is not the only or necessary or limiting consequence. We have seen this and know also that television can solicit deep attention, why not grant the possibility that these forms have a role in progressive political transformation as well?

Lenin, to pick an explicitly 'delinquent' case, argued that the Party had to use the most advanced modes of communication in making its struggle known. ${ }^{46}$ The Soviets need not only electrification and Pravda, but have to express the revolutionary project in whatever means are available, in order to both communicate through and transform these media. The revolutionary project is another form of care of course, with a longer circuit perhaps than family and educational institutions, but also aiming to transform these, to sublate the things that capitalism brings in ways that are not exploitative nor oppressive. The old mole grubs up again over long cycles, as Marx noted. Mao too wrote much on the care that the revolutionary army must take in its work with the mass peasantry; ${ }^{47}$ there is something here too to consider in terms of another circuit, an involvement in national and international communism that must itself be patient, especially, perhaps, with philosophy. These are however topics for a different paper.

I thank Ben Roberts, Sophie Fuggle, Joanna Figiel, Lara Choksey, Inigo Wilkins, Camille Barbagallo, Heidi Hasbrouck, Alison Hulme and the anonymous new formations readers for help on this text.
46. Of course I do not think Lenin is delinquent in any way that should be condemned, Vladimir I. Lenin, 'Party Organisation and Party Literature' in Collected Works Volume 10, Moscow, Progress Publishers (1905) 1962, pp4449.

47. Mao Tse-Tung, 'Serve the People' Selected Works Volume 2, Peking, Foreign Languages Press, (1944) 1967, pp177178. 